Vol. 6, No. 21, Part Four, Nov. 2017, PP. 31 - 68

\title{
Dififerences in Verbal and Non-verbal Linguistic Communication between Children with Mild Intellectual Disability and Children with Hig̉h Functioning Autism on AL-Ahssa in the Kingdom of Saudi Arabia
}

\author{
By \\ Sawsan Alelaiwi \\ Instructor at Special Education Program \\ BS. Special Education - Hearing Impairment \\ Master at Special Education- Severe Disabilities \\ Umm Al Qura University
}


Difierences in Verbal and Non-verbal Linguistic Communication between Children with Mild Intellectual Disability and Children with High Functioning Autism on AL-Ahssa in the Kingdom of Saudi Arabia

\author{
By \\ Sawsan Alelaiwi(")
}

\begin{abstract}
Ahstract
The present study aimed at identifying the differences in verbal and non-verbal linguistic communication between children with mild intellectual disability and children with high functioning autism in the Kingdome of Saudi Arabia. The Sample included (60) children, (30) had mild Intellectual disability, and (30) with high functioning autism. Children with mild intellectual disability were recruited from mainstream schools. As for the children with high functioning autism were recruited from both mainstream schools and specialized educational center located in Al-hasa'a district. A measure of a verbal and non-verbal linguistic communication was used as a tool to achieve the main objectives of the present study. The tool was applied individually. Results showed a significant difference in the average of the non- verbal linguistic communication scores between children with mild Intellectual disability and children with high functioning autism. Children with mild intellectual disability displayed better nonverbal linguistic communication in comparison to children with high functioning autism. Moreover, no significant difference was found in the average of the verbal- linguistic communication scores between children with mild intellectual disability and children with high functioning autism. Finally, no significant difference was found between the average of verbal and non - verbal linguistic communication score of children with mild Intellectual disability and children with high functioning autism according to the age group.
\end{abstract}

Terms Keys: verbal and non-verbal, linguistic communication, mild intellectual disability, high functioning autism,

$(*)$ Instructor at Special Education Program, BS. Special Education - Hearing Impairment, Master at Special Education- Severe Disabilities, Umm Al Qura University 


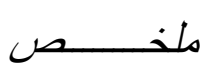

تهدف الدراسة الحالية إلى التعرف على الفروق في التواصل اللغوي اللفظي وغير اللفظي

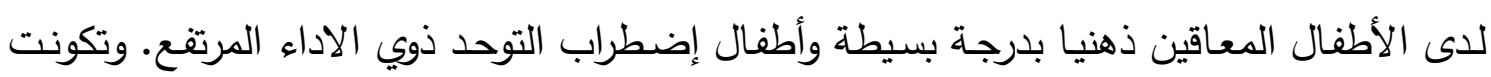
عينة الدراسة من (• (7) طفلا من أطفال المعاقين ذهنيا بدرجة بسيطة من مدارس الدمج، وأطفال

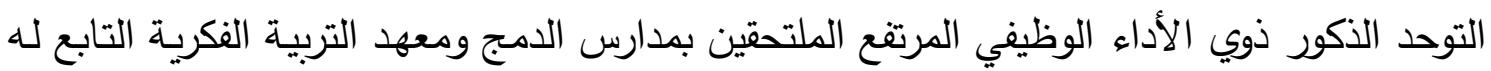
برنامج التوحد في الأحساء بالمملكة العربية السعودية ، وقد تم إختيارها بالطريقة القصدية بواقع لهع

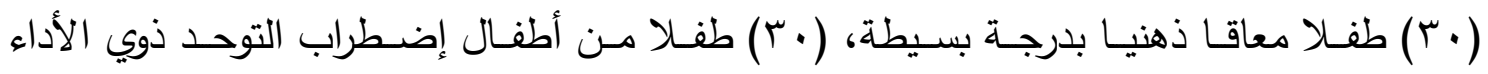
الوظيفي المرتفع. ولتحقيق اهداف الدرسة، فقد تم استخدام مقياس التواصل اللغوي اللفظي وغير اللفظي إعداد الباحثة. وقد أشارت النتائج إلى وجود فروق دالة إحصائيا في متوسط درجة التواصل اللغوي غير اللفظي بين الأطفال المعاقين ذهنيا بدرجة بسيطة وأطفال إضطراب التوحد ذوي الأداء

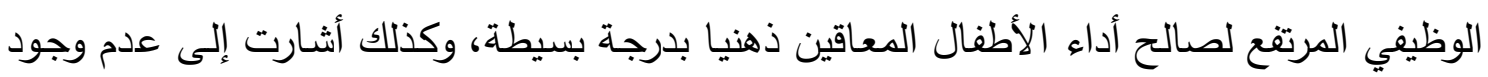

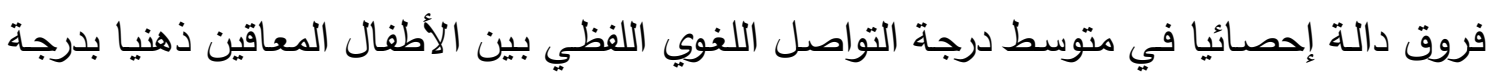
بسيطة وأطفال إضطراب التوحد. كما أشـارت النتائج إلى عدم وجود فروق دالة إحصائيا بين متوسط درجة التواصل اللغوي اللفظي وغير اللفظي لدى كل من الأطفال المعاقين ذهنيا بدرجـة بسيطة وأطفال التوحد ذوي الأداء الوظيفي المرتفع وفقا للمرحلة العمرية.

الكلمـات المفتاحيـة: التواصل اللغوي اللفظي وغير اللفظي، الإعاقة الذهنية البسيطة، إضطراب

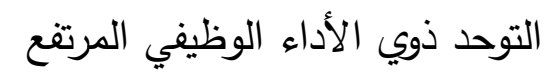




\section{Introduction}

Language is evolving rapidly in the early years of a child's life. It can clearly observe this evolution in early childhood. Language is the basis for many skills that the child acquired such as (a communication whether is verbal as speech or nonverbal as body language or sign language, etc.). Most of research defines language as the system we used to communicate ideas and includes both expressive language, through which we send messages, and receptive language, through which we receive and understand messages (Taylor, Smiley \& Richards, 2015). We use language to inform others around us of what we feel, what we desire, and question/understand the world around us. We communicate effectively with our words, gestures, and tone of voice in a multitude of situation. Therefore, language is the most important elements of communication, problem solving and expand the knowledge, integration, analysis and accumulation. The deficiencies of the language can cause a severe impact on the ability of the individual to learn efficiently and confidently. In addition it can impact the interaction with the environment around him/her. The use of language is influenced by the extent to accommodate the person's words or ideas inside the memory speed. The deficiency of the language is one of the most important characteristics that has with student with Intellectual disabilities and student with High Functioning Autism. Based on the Characteristics of language for student with Intellectual disability (ID) that Taylor, Smiley \& Richards (2015) found, that there is considerable evidence that many students with Intellectual disabilities follow the same basic order of language development as students without intellectual disabilities. However, language development, as whole, may be 
delayed for this group. For example, students could experience delays in learning vocabulary or engaging adequately in the give- and- take of conversation. Difficulties in memory may contribute to this problem, affecting the ability of some students to construct more complex verbal messages. In addition, a child may not adequately remember the events of two days ago to be able to tell others what was occurring at that time in the proper order and without omission of events. Speech disorders also might accompany language delays. Various studies indicate the presence of significant speech problems in students with Intellectual disabilities, including articulation, voice, and fluency problems. As well as, the characteristics of language for student with High Functioning Autism have a deficit in communication skills are very common in individuals with autism. Because of the importance of communication in developing social relationship, it is actually difficult to separate the two areas. For example, child with autism who is unable to communicate as expected with peers might have a very difficult time establishing friendship with them. Communication deficits in individuals with autism can be divided in two categories: deviations in language development and specific deficits related to communicative intent. As I defined the language for students with mild intellectual disabilities and high functioning autism is important though to define the communication for students with mild intellectual disabilities and high functioning autism.

Beblawi, (2006), has been defined communication as the process: The process includes the exchange of information, feelings, thoughts, and beliefs among humans, and this includes communication both: (spoken language, and audio, and written) and means non-verbal (sign language, 
spelling of the fingers, lip-reading, language the eyes, and the movements of hands and feet). The communication skills that a child learns early in life will be the foundation for his or her communication abilities for the future. Strong language skills are an asset that will promote a lifetime of effective communication.

Communication can occur without speech and can take many different forms. A raised eyebrow, a sigh and a smile can all convey different message.

Taylor, Smiley, and Richareds (2015), indicate that the severity levels be indicated in the areas of social communication and restricted, repetitive behaviors. Three levels are indicated from level 1 (requiring support) to level 3 (requiring very substantial support). And they found that, autism means a development disability significantly affecting verbal and nonverbal communication and social interaction, generally evident before age three that adversely affects child's educational performance. Other characteristics often associated with autism are engagement in repetitive activities and stereotyped movement, resistance to environmental change or change in daily routines, and unusual responses to sensory experiences, Taylor, Smiley, and Richareds (2015, Pp.340, 341).

Gillberg \& Coleman, (2000) found that, children with autism generally display several deviations in language development. Often they may use a few to several words by age 2, but then stop speaking for one or more years, and in some cases, may never speak again One language characteristic displayed by many children with autism is echolalia. "The parroting" or repeating of words and phrases said to them. For example, if a child is asked "How are you today"? She or he may respond with the same 
phrase, "How are you today"? Echolalia can be either immediate, as the previous example, or delayed, in which the child repeats a previously heard word or phrase hours, days, or weeks later. Other less prevalent language characteristics are palilalia, when the child repeats his or her own words; echopraxia, the repetition of others' gestures and movements, and using made-up words called neologisms. Another common language characteristics with autism may refer to themselves by their name instead of "I " or "me " For example, "Brandon want the toy" rather than "I want the toy" Other characteristics are inappropriate use of short, incomplete sentence (Taylor, Smiley \& Richards, 2015).

The primary function of language is communication. Many individuals with autism have deficits in communication intent or conveying the intended meaning. Even if normal language patterns are intact, communication problems can exist, For example, some individuals with high-functioning autism develop relatively sophisticated language abilities, such as vocabulary skills and acknowledge of grammatical structure, their ability to use language for communication in real- life situations is some times masked. "For example, a student with autism who is having difficulty understanding the intent of peer's conversation might use good vocabulary, but what is said may be totally unrelated to the peer's comments. Speech problems, such as unusual intonation or rhythm, might also lead to difficulties in conversational skills. In addition, children with autism frequently do not use nonverbal communication skills, such as gesturing that are used by others to help convey meaning.

One specific communication characteristics that can result in the problems is the tendency for individuals with autism to comprehend or 
interpret information very literally (Taylor, Smiley, and Richareds, 2015, Pp.345, 346).

\section{Literature Review:}

Most of the studies whether foreign or Arab studies detects that language development of the child moving in sequential stages of age with the Featured characteristics of each stage. These studies also demonstrated that the linguistic dictionary for children at each of these stages, whether dictionary or operative concept differs from the other phases. According to identify deficiencies in the communication skills of language development in children with Mild Intellectual Disability and Children with High Functioning Autism, this study examine the extent of the need to provide the necessary needs of therapeutic and educational programs aimed at developing communicative skills of these categories. In this sense, this study tried to identify the differences in linguistic communication verbal and non-verbal children with Mild Intellectual Disability and Children with High Functioning Autism.

\section{Description of the Research Problem:}

effective communication can affect on human life in several aspects in the social life such as work, school, home and another environment. Language plays, in addition, a key role in the all of subjects that learned by the individual over the course of his/her life. On the other hand, communication disorder is one of the most important problems that individuals with Mild Intellectual Disability and Children with HFA has. The performance of communication and language disorder are among the greatest problems of the children with Intellectual Disabilities. They would 
be hampered by the individual compatibility with the environment. Children with ID have abilities impairment to express their needs and desires and abilities impairment to understand the desires of others and knowledge of the world around him/her. The improvement of the language that they have was located in the lower level of the other capacity level (Taylor, Smiley \& Richards, 2015). Also children with intellectual disabilities are suffering from the general decline in linguistic performance if compared to their non - disabled children, whether it's verbal or nonverbal skills in receptive and expressive language. Also, children with ID shows a failure to understand the things that they listen to, and the difficulty in linking the meanings of new words of the information that a child may be acquired by, and disturbances in the audiovisual memory (Roussan, 2017).

Children with autism suffer from a lack of communication, whether verbal or non-verbal, where there are $50 \%$ of them, at least do not grow their language at all, and therefore not be able to use language to talk or use it to communicate, either the remaining percentage, it suffers from a clear lack of language growth have since delayed that growth significantly, and they have only a few words, and yet not be able to be used in the context of the language properly in order to indicate the meaning of which we know, that they do not use them properly, as well as the understanding of suffering from various disorders in pronunciation (Taylor, Smiley \& Richards, 2015). On the other hand, the expressive language with autistic children are repetitive, and repeating the speech Echolalia, and speech typical of those words that they know, and the inability to conduct reciprocal conversations with others any inability to establish a dialogue or 
a conversation with them, and the replacement of pronouns, and the tone of voice. The rhythm of their own is unusual, not to mention the abnormal use or non-ordinary gestures. On the other hand, the language of internal Language of any ability to pretend or imaginative play represents another aspect of palaces from which they suffer. The ability to understand and comprehension on the other hand they are very limited, and they are unable to understand and grasp abstract concepts (Alqraiti, 2005). The results of previous studies indicated that the linguistic characteristics of the students with ID is vary according to age group, where (in Jetaili ,2009) that the younger children are making the best levels in the language in their earnings. Also Alharan, (2009) indicated that there are differences in the level of understanding of linguistic structures depending on the variable chronological age. The results of previous studies also indicated that the linguistic characteristics of children with autism are affected by a factor of chronological age. In the study of Badr (2011), results showed that one of the most way or method that used by the sample of children between the ages of 5-9 years were based on the use of facial expressions, especially the eyes and smile as a means of communication (nonverbal). As well as Grzin study (2008), which found that children with the youngest aged from 12-15 months have delayed language development of autism. It was noted by the inability to communicate non-verbal than normal children, the youngest, it was a non-verbal communication in children with autism younger less compared to the other category. Smith, Miranda\& Zoidman, (2007) found that, Children with autism younger ages than a year and a half to six years was the development rate they have in the vocabulary of children less than latecomers linguistically. In the light of these facts, as a researcher, I would 
mentioned the purpose of this study which, is to detect and identify the differences in the dimensions of linguistic communication between the children with Mild Intellectual Disability and children with HFA through the following questions:

1) Are there any differences in the dimensions of linguistic communication between the Mild Intellectual Disability and Children with High Functioning Autism?

2) Are there any differences in linguistic communication dimensions of the Mild Intellectual Disability according to Group age 7 - 9 and 9 11

3) Are there any differences in the dimensions of the language to communicate with autistic children those with high functioning according to Group age 7 - 9 and $9-11$ ?

\section{Hypotheses:}

children with mild intellectual disability displayed better non- verbal linguistic communication in comparison to children with high functioning autism. (Directional)

There is no significant difference was in the average of the verballinguistic communication scores between children with mild intellectual disability and children with high functioning autism. (None-directional).

There is no significant difference was between the average of verbal and non - verbal linguistic communication score of children with mild Intellectual disability and children with high functioning autism according to the age group. (None- directional). 


\section{Population:}

male students with mild intellectual disability and high function of autism that are inclusion in the regular class in Saudi Arabia in AL-Ahassa region. Students were selected from Houtain School, Tobari School, and Educational autism in Mild ID Institution. Population was 132 of MI and 116 of HFA. The numbers of disabled children with mild intellectual disability that are between the ages ( 7 to less than 9 years) 60 children, and the number of children ages (9 to 11 years) 72 children with disabilities Statistics mentality, and the number of male of autism with high functioning children that are belong to the institution of intellectual disability and autism educational program are 52 children. Where the numbers of children with autism with high functioning aged from (7 to less than 9 years) 36 children, and the numbers of children aged from (9 to 11 years) 28 children. As well as, the number of children with autism in the regular schools system are12 children, ( 7 to less than 9 years) 6 children, and children who reached the age of (9 to 11 years) 6 children.

\section{Sampling:}

60 male children with mild intellectual disability, and 30 male children with autism with high functioning who are inclusion in the regular class. And 10 male children with autism with high functioning who are in the inclusion school system, and 20 children who are belong to the institution of intellectual disability and autism educational program. Their aged are between ( 7 to less than 9 years) and ( 9 to 11 years). They are selected purposely based on the following criteria: 
- To be children who have been previously diagnosed by psychologist of MI disability and HFA

- To be children with MI who are included in the regular classroom and children with autism with high functioning who are belong to the institution of intellectual disability and autism educational program

- Don't have other disabilities

- Age is 7 up to 11 years

- Enrollment of children in inclusion schools, and autism program shall not be less than one year so as to ensure knowledge of the teacher or specialist to do the application of the scale it.

Table 1: shows the number of children and distribution by type of disability, age group and educational institution to which they belong.

\begin{tabular}{|cccc|}
\hline $\begin{array}{c}(9-11) \\
\text { Autism Mild } \\
\text { ID }\end{array}$ & Autism & $\begin{array}{c}\text { (7-9) } \\
\text { Mild ID }\end{array}$ & $\begin{array}{c}\text { Aged group and } \\
\text { educational } \\
\text { institution }\end{array}$ \\
\hline 6 & 4 & 8 & Houtain School \\
8 & - & 7 & Tobari School \\
$-\quad 7$ & 10 & - & $\begin{array}{c}\text { Educational } \\
10\end{array}$ \\
16 & 14 & 15 & $\begin{array}{c}\text { autism in Mild ID } \\
\text { Institution } \\
15\end{array}$ \\
& 60 & & Total \\
\hline
\end{tabular}

\section{Variables under research terms:}

a) Dependent variable: Linguistic communication verbal and nonverbal.

- Operational definition is the degrees to which it gets screened after the non- verbal communicate in linguistic communication of verbal and non-verbal scale. 


\section{b) Independent variable:}

- Group of age from (7 to less than 9) and (9-11) years.

- Children with mild intellectual disability and children with high functioning performance.

- The operation definition of children with mild intellectual disability are male children enrolled in regular schools in inclusion classroom according to the terms of enrollment, where the child's intelligence coefficient ranges between (55-70) degrees on a Wechsler Intelligence scale or (52-68) on the Stanford Binet scale, which ranges from the ages of ( 7 to less than 9), and between (9 to 11), and those who do not suffer from other disabilities associated with mental disability Statistics.

- The operation definition of children with autism with high functioning performance are male children with high functioning performance according to the estimate of their teachers who accept the terms and enrolled in the program Autism apply to them in the intellectual Institute for Special Needs in Al- ahsa and aged ( 7 to less than 9) and (9 to 11), and enrolled in a regular school in inclusion classroom and institutes of intellectual disability.

- This study was conducted in Al-Ahsa province school integration program of the Institute of Intellectual Education autism.

\section{Research Design:}

The study used a comparative approach; it has been chosen based on the suitability of the nature of the study. Because the comparative approach 
is the approach that deals with the phenomena, analysis and interpretation using scanning and comparison methods that have been used in the current study. Since this study aims to identify the dimensions of linguistic communication with mild intellectual disabilities and autistics children with high functioning detection of differences between them in accordance with the variable from ( 7 to less than 9 years old) and ( 9 to 11 years) in the Kingdom of Saudi Arabia Eastern Province in Al-Ahsa province. Researcher's limitation at this study was the difficulty of communication with professional's teachers who teaching students with mild intellectual disabilities, and students with high functioning of autism for male schools in Saudi Arabia in Al-Ahsa province. It was hard to communicate with them at the appropriate time, especially; right now researcher is in different country from research study. Researcher is at the USA and the study accure in Saudi Arabia at al Ahsa province. For researcher's advantage was getting the right sample for research study. It was easy to get male sample than get female sample of this study. Researcher get collaborative group to participate at this study, and provide me data that I need. Researcher used teacher's interviews test scale, and questioners.

\section{Data Collection Instruments and Administration:}

First, research Has been viewed the child's files by contacting with teacher's of disable students with the help of social workers, to count the numbers of children who aged are between (7 to less than 9) and (9 to 11 years). That will be separately for each category. Researcher was checked of the accuracy of the time-age account. Second, researcher has been viewed on the acceptance records diagnosed cases and psychological examination through diagnosis centers and school forms; children of 
mental disability diagnosed test adopted (Stanford Binet) and the measure of adaptive behavior for children in order to determine the severity of the disability, were excluded children whose conditions of sample selection of the category does not apply to them disability Statistics mental, and children with autism those with high functioning was adopted in the diagnosis of intellectual education center, which was adopted on the diagnosis of psychiatry, and mentions only the report diagnose the condition and severity, and therefore has been limited to autistic children with high functioning in the Institute of the intellectual Education program that belong to the autism program.

\section{Tools of the Instruments:}

Is built a scale study in accordance to local environment, the target group for the type of disability. The scale consists of two dimensions (linguistic verbal communication, and linguistic with nonverbal communication).

- Researcher put the scale. It was in the primary from of the present instrument of two dimensions of linguistic communication verbal language and non-verbal communication.

- The scale has been standard on ten presenters. One of the members was faculty of the University of Imam Muhammad bin Saud in Riyadh members, and two members of the teaching in the Arabian Gulf University special education, and five members of the faculty at King Faisal University Al ahsa Education Department special (Intellectual disability and Autism), and two from King Abdul Aziz University in Jeddah - special education department, in order to ascertain the extent appropriate measure of the areas measured by 
(linguistic communication verbal and non-verbal dimensions) among the study groups in terms of type of disability, age range for each category, as well as ascertain the extent appropriate paragraphs dimension to which they belong and the goal that developed from him, the integrity of the language of the items of the scale, has been extracting approval ratio was $90 \%$, based on the recommendations and observations of the arbitrators been reworded some test items. For examples of this before the amendment "speak softly" after the amendment became "echoing voices is clear and understandable" and "speak with stops or some interruptions irregular" occurs after the amendment became "speak with the occurrence of stops and some interruptions irregular" and "read sentences consist of song" has become after the amendment "say or state sentences consist of words. Please see the scale below in the end of the study.

- The scale consists of child's name, age, level, school or center's name, and examiner's name.

- The scale includes (70) sentences. The first (35) paragraph or sentences for language verbal communication" and the second part of (35) sentences for linguistic non-verbal communication.

- How to implement the scale? The scale consists of 4 choices: always, sometime, seldom, and never. First: professionals teacher will response for each sentence of the scale in a quiet room through observing students in verbal and non-verbal communication. The scale will impalement individually for each student. Teachers will mark ( $\mathrm{Q}$ ) toward the sentence that child do it always and constantly. Teacher will mark ( $\quad$ ) toward the sentence that child do 
it sometimes. Teachers will mark ( $\mathrm{Q})$ toward the sentence that child do it rarely. Teachers will mark ( $\mathrm{\square})$ toward the sentence that child doesn't do it ever.

- Second: correcting the scale, the degree of the sentences of linguistic communication verbal and non-verbal measure as the fallowing: (always $=4$ degrees), (sometimes $=3$ degrees), (rarely $=2$ degrees), (never $=1$ degree). Knowing that each dimension consists of (35) items ranging grades that can be obtained by an individual between 35-140 after all, and the dimensions or the scale of the whole 70-280 degrees.

\section{Instrument Validity:}

Content: the scale was to verify the authenticity of linguistic communication measure by introducing the primary image on a group of arbitrators with experience and competence in the field of intellectual disabilities and autism, special education, and measurement and evaluation, and the Arabic language so that they were asked to express an opinion on the appropriateness of the sentences of the dimensions to which they belong, and suitability for the purposes of the study, and the clarity of those sentences of the language aspect, and any other views they see in their formulation to improve the usefulness of the scale and scalability. Based on the observations of arbitrators and their suggestions have been appropriate adjustments have been accepted paragraphs that got 90 percent agreement.

Construct: To ascertain the veracity of the internal construction of the scale of linguistic communication, it has been applied on a prospective sample of mild intellectual disability of children in intellectual institutes, and children with autism with high functioning governorate of Al-Ahsa. 
There were 30 children, of which 15 children with disabilities Statistics mental, and (15) children from autistic children those with high functioning was a scout study separately, and use the Pearson correlation coefficient for the detection of the correlation between the vertebrae scale dimensions, which belong to linguistic communication verbal and non-LVC. Table 2 shows the results of correlation coefficients.

\begin{tabular}{|l|l|l|l|l|l|l|l|l|l|l|l|}
\hline LNVC & SNo & LNVC & SNo. & LNVC & SNo. & LVC & SNo. & LVC & SNo. & LVC & Item \\
\hline 0.10 & 25 & $* 0.37$ & 13 & 0.24 & 1 & $* * 0.63$ & 25 & $* * 0.78$ & 13 & 0.31 & 1 \\
\hline 0.19 & 26 & $* * 0.48$ & 14 & $* * 0.53$ & 2 & $* * 0.69$ & 26 & $* * 0.72$ & 14 & 0.33 & 2 \\
\hline$* * 0.60$ & 27 & 0.16 & 15 & $* * 0.60$ & 3 & $* * 0.72$ & 27 & $* * 0.72$ & 15 & $* 0.46$ & 3 \\
\hline$* * 0.60$ & 28 & $* * 0.50$ & 16 & 0.34 & 4 & $* * 0.75$ & 28 & $* * 0.64$ & 16 & 0.27 & 4 \\
\hline$* * 0.58$ & 29 & $* * 0.57$ & 17 & $* 0.43$ & 5 & $* * 0.74$ & 29 & $* * 0.62$ & 17 & $* * 0.61$ & 5 \\
\hline$* * 0.54$ & 30 & $* 0.37$ & 18 & 0.31 & 6 & $* * 0.76$ & 30 & $* * 0.60$ & 18 & $* * 0.68$ & 6 \\
\hline 0.32 & 31 & $* 0.43$ & 19 & 0.14 & 7 & $* * 0.46$ & 31 & 0.22 & 19 & $* * 0.49$ & 7 \\
\hline 0.44 & 32 & 0.29 & 20 & 0.30 & 8 & $* * 0.54$ & 32 & $* * 0.60$ & 20 & $* 0.44$ & 8 \\
\hline$* * 0.54$ & 33 & $* * 0.51$ & 21 & $* 0.43$ & 9 & $* * 0.59$ & 33 & $* * 0.53$ & 21 & $* * 0.66$ & 9 \\
\hline $0.90-$ & 34 & 0.33 & 22 & $* * 0.53$ & 10 & $* * 0.74$ & 34 & $* * 0.72$ & 22 & $* * 0.57$ & 10 \\
\hline 0.14 & 35 & $* * 0.56$ & 23 & $* * 0.50$ & 11 & $* * 0.57$ & 35 & $* * 0.50$ & 23 & $* * 0.55$ & 11 \\
\hline & & $* 0.41$ & 24 & $* 0.39$ & 12 & & & $* 0.37$ & 24 & $* * 0.62$ & 12 \\
\hline
\end{tabular}

Pearson correlation coefficient of the relationship between the sentences of the scale and its relation to the dimensions to which they belong (Sentence No. $=$ SNo., Linguistic Verbal Communication $=$ LVC, Linguistic None- Verbal Communication= LNVC) ** Significance 0.01 level * at 0.05 level

- Results in table (2) showed that positive and significant correlation between LVC and non-LVC ranged from 0.22-0.78. 
- The results indicated that the correlation dimension sentences of linguistic non-verbal communication to which they belong, ranging from coefficients values (-0.09- 0.60).

- Also researcher has been confirmed the veracity of the scale, by using the Pearson correlation coefficient for the detection of the correlation between the scale dimensions to each other on the one hand, and its relation to the total dimensions on the other hand, Table 3 shows the results of correlation coefficients.

\begin{tabular}{|c|c|c|c|}
\hline $\begin{array}{c}\text { The } \\
\text { Total }\end{array}$ & $\begin{array}{c}\text { Linguistic and } \\
\text { None verbal } \\
\text { communication }\end{array}$ & $\begin{array}{c}\text { Linguistic } \\
\text { verbal } \\
\text { communication }\end{array}$ & Dimensional \\
\hline$* * 0.93$ & $* * 0.48$ & - & Linguistic verbal communication \\
\hline$* * 0.77$ & - & & $\begin{array}{c}\text { Linguistic and None verbal } \\
\text { communication }\end{array}$ \\
\hline
\end{tabular}

** Significance 0.01 level

- Correlation coefficients in table (3) were positive and significant at 0.01 levels.

- Results indicated correlation between the dimensions of measure coefficients values (linguistic verbal communication, non-verbal language to communicate) to the total dimensions were $(0.77$, $0.93)$, respectively, which is statistically significant at the 0.01 levels.

- So the overall results reached indicate that linguistic communication measure features highly suitable for the purposes of the present study sincerity. 


\section{Instrument Reliability (internal consistency):}

Internal consistency using Cronbach's Alpha of the final from of the LVC using sample of 15 ID children, and 15 HFA results are presented in table (4). Results are high enough to conform the reliability of the LVC scale.

\begin{tabular}{|c|c|}
\hline Cronbach's alpha & Dimensional \\
\hline 0.94 & Linguistic verbal communication \\
\hline 0.82 & Linguistic and None verbal communication \\
\hline 0.93 & The Test as a Whole \\
\hline
\end{tabular}

Cronbach's alpha coefficients values for the dimensions of linguistic communication measure

Evidenced by the results of the analysis to the schedule that the reliability coefficients values dimensions of language verbal communication measure and none-verbal communication using Cronbach's alpha coefficient was $(0.82,0.94)$ respectively, and amounted reliability coefficient to the total dimensions (0.93).

So based on the results of reliability coefficients reached values, it can be argued that linguistic communication measure is characterized by a good degree of constancy suit the purposes of the present study.

The scale of linguistic communication verbal and non-verbal of children with mild intellectual disabilities children with autism with high functioning and as a result of the arbitrators. 


\section{1) Dimension of linguistic verbal communication:}

\begin{tabular}{|c|c|c|c|c|}
\hline $\begin{array}{l}\text { Sentences } \\
\text { No. }\end{array}$ & Sentences & $\begin{array}{l}\text { Appropriat } \\
\text { e dimension } \\
\text { sentence for } \\
\text { arbitrators }\end{array}$ & $\begin{array}{l}\text { Inappropriat } \\
\text { e dimension } \\
\text { sentence for } \\
\text { arbitrators }\end{array}$ & $\begin{array}{l}\text { Linguistic formulation } \\
\text { integrity after amendment }\end{array}$ \\
\hline 1 & $\begin{array}{l}\text { Speaking in a low } \\
\text { voice }\end{array}$ & 8 & 2 & $\begin{array}{l}\text { Speaking as the appropriate } \\
\text { information }\end{array}$ \\
\hline 2 & Speaking fast & 8 & 1 & $\begin{array}{l}\text { Speaking as the appropriate with } \\
\text { the situations }\end{array}$ \\
\hline 3 & $\begin{array}{l}\text { Speak with stop or } \\
\text { discontinuous words }\end{array}$ & 8 & 1 & $\begin{array}{c}\text {-Speech with clear stop and disorder } \\
\text { - Speech and stop during speech } \\
\text { irregularly }\end{array}$ \\
\hline 4 & $\begin{array}{l}\text { Speak and use some } \\
\text { vocalizations }\end{array}$ & 6 & 3 & \\
\hline 5 & $\begin{array}{l}\text { Read sentence } \\
\text { consists of words }\end{array}$ & 8 & 1 & State sentences consist of words \\
\hline 6 & $\begin{array}{c}\text { Describe actions } \\
\text { during picture } \\
\text { descriptive } \\
\end{array}$ & 7 & $\begin{array}{l}2 \text { appropriate } \\
\text { for ID }\end{array}$ & \\
\hline 7 & State familiar things & 8 & 1 & $\begin{array}{l}\text { State names of familiar objects } \\
\text { in the environment }\end{array}$ \\
\hline 8 & $\begin{array}{l}\text { Ask about things in } \\
\text { appropriate name }\end{array}$ & 8 & 1 & \\
\hline 9 & $\begin{array}{l}\text { Pronounced letters } \\
\text { correctly }\end{array}$ & 8 & 1 & \\
\hline 10 & $\begin{array}{l}\text { Used appropriate pitch } \\
\text { to the subject of talk }\end{array}$ & 8 & 1 & $\begin{array}{l}\text { Used appropriate sensory } \\
\text { framework }\end{array}$ \\
\hline 11 & $\begin{array}{l}\text { Has a fluent in } \\
\text { speaking without } \\
\text { hesitation or stutter. }\end{array}$ & 8 & 1 & \\
\hline 12 & $\begin{array}{l}\text { Can express verbally } \\
\text { when participating in } \\
\text { a simple conversation } \\
\text { with a school or } \\
\text { teacher. }\end{array}$ & 8 & 1 & \\
\hline 13 & $\begin{array}{l}\text { Can express his ideas } \\
\text { in sequence and } \\
\text { follow up properly. }\end{array}$ & 8 & 1 & $\begin{array}{c}\text { Can express his ideas in } \\
\text { sequences as suitable for his age }\end{array}$ \\
\hline 14 & $\begin{array}{l}\text { Take into account in } \\
\text { his singular and } \\
\text { plural. }\end{array}$ & 8 & 1 & \\
\hline 15 & $\begin{array}{l}\text { Can use (I, she, he, } \\
\text { we, they.etc.) }\end{array}$ & 8 & $\begin{array}{l}1 \text { appropriate } \\
\text { for ID }\end{array}$ & Can use (I, she, he, we, they.etc.) \\
\hline 16 & $\begin{array}{l}\text { Can repeat what he } \\
\text { hears }\end{array}$ & 8 & 1 & \\
\hline 17 & $\begin{array}{l}\text { Understands verb } \\
\text { times past, present } \\
\text { and future }\end{array}$ & 8 & 1 & \\
\hline 18 & $\begin{array}{l}\text { Used possessive } \\
\text { accuracy }\end{array}$ & 8 & 1 & \\
\hline 19 & $\begin{array}{c}\text { It can be named } \\
\text { properly }\end{array}$ & 8 & 1 & \\
\hline
\end{tabular}




\begin{tabular}{|c|c|c|c|c|}
\hline $\begin{array}{l}\text { Sentences } \\
\text { No. }\end{array}$ & Sentences & $\begin{array}{l}\text { Appropriat } \\
\text { e dimension } \\
\text { sentence for } \\
\text { arbitrators } \\
\end{array}$ & $\begin{array}{l}\text { Inappropriat } \\
\text { e dimension } \\
\text { sentence for } \\
\text { arbitrators } \\
\end{array}$ & $\begin{array}{c}\text { Linguistic formulation } \\
\text { integrity after amendment }\end{array}$ \\
\hline 20 & $\begin{array}{c}\text { Can told his age when } \\
\text { someone asked him }\end{array}$ & 8 & $\begin{array}{l}1 \text { Acquired } \\
\text { after training }\end{array}$ & \\
\hline 21 & $\begin{array}{l}\text { Can mention his } \\
\text { parents and his } \\
\text { brothers name } \\
\text { correctly } \\
\end{array}$ & 8 & 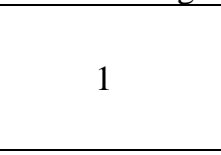 & \\
\hline 22 & $\begin{array}{l}\text { Can mention the } \\
\text { name of his school } \\
\text { properly }\end{array}$ & 8 & 1 & \\
\hline 23 & $\begin{array}{c}\text { Trends uses words } \\
\text { (North South East } \\
\text { West) }\end{array}$ & 8 & 1 cognitive & $\begin{array}{l}\text { Can use (above, under, behind, } \\
\text { infront) }\end{array}$ \\
\hline 24 & $\begin{array}{l}\text { State body parts } \\
\text { correctly }\end{array}$ & 8 & 1 & $\begin{array}{l}\text { State body parts and functions as } \\
\text { much as possible }\end{array}$ \\
\hline 25 & $\begin{array}{l}\text { Used propositions } \\
\text { during the } \\
\text { conversation }\end{array}$ & 8 & 1 & \\
\hline 26 & $\begin{array}{l}\text { Used words such as } \\
\text { please when he asked } \\
\text { people }\end{array}$ & 8 & $\begin{array}{l}1 \text { Must be } \\
\text { intensive } \\
\text { training }\end{array}$ & \\
\hline 27 & $\begin{array}{l}\text { Called friends and } \\
\text { teachers when asked } \\
\text { to do so }\end{array}$ & 8 & 1 & \\
\hline 28 & $\begin{array}{c}\text { Uses phrases include } \\
\text { names }\end{array}$ & 7 & 2 & \\
\hline 29 & $\begin{array}{l}\text { Uses the word (thank } \\
\text { you) when he wants } \\
\text { to thank one }\end{array}$ & 7 & 2 & After training \\
\hline 30 & $\begin{array}{c}\text { Can ask questions } \\
\text { verbally }\end{array}$ & 8 & 1 & \\
\hline 31 & $\begin{array}{c}\text { Can express verbally } \\
\text { for an easy topics of } \\
\text { environment }\end{array}$ & 8 & 1 & \\
\hline 32 & $\begin{array}{c}\text { Repeats the words he } \\
\text { hears }\end{array}$ & 8 & & \\
\hline 33 & $\begin{array}{l}\text { Take the initiative to } \\
\text { talk with peers }\end{array}$ & 8 & 1 & Able on dialogue \\
\hline 34 & $\begin{array}{l}\text { Uses the word 'yes' } \\
\text { and 'no' as required } \\
\text { by the situation }\end{array}$ & 8 & & \\
\hline 35 & $\begin{array}{l}\text { Echoing voices is } \\
\text { clear and } \\
\text { understandable }\end{array}$ & 8 & & Echoing voices not understood \\
\hline 36 & $\begin{array}{c}\text { Answer correctly the } \\
\text { questions that relate } \\
\text { to a particular } \\
\text { situation or story may } \\
\text { be heard }\end{array}$ & 8 & 1 & \\
\hline 37 & $\begin{array}{l}\text { Speaking patterns of } \\
\text { words is not balanced }\end{array}$ & 8 & 1 & \\
\hline
\end{tabular}




\section{2) Linguistic of none- verbal communication:}

\begin{tabular}{|c|c|c|c|c|}
\hline $\begin{array}{l}\text { Sentences } \\
\text { No. }\end{array}$ & Sentences & $\begin{array}{l}\text { Appropriate } \\
\text { dimension } \\
\text { sentence for } \\
\text { arbitrators }\end{array}$ & $\begin{array}{l}\text { Inappropriate } \\
\text { dimension } \\
\text { sentence for } \\
\text { arbitrators } \\
\end{array}$ & $\begin{array}{c}\text { Linguistic formulation } \\
\text { integrity after } \\
\text { amendment }\end{array}$ \\
\hline 1 & $\begin{array}{c}\text { Looks at the eyes of } \\
\text { those who speak }\end{array}$ & 7 & 2 & \\
\hline 2 & $\begin{array}{c}\text { Listens for a moment } \\
\text { at least when talking } \\
\text { with anyone }\end{array}$ & 8 & 1 & \\
\hline 3 & $\begin{array}{l}\text { Head stir demonstrates } \\
\text { his understanding of } \\
\text { what is meant by the } \\
\text { word not }\end{array}$ & 8 & 1 & $\begin{array}{c}\text { His head is demonstrating } \\
\text { an understanding of what } \\
\text { is meant by the word not } \\
\text { and the word yes }\end{array}$ \\
\hline 4 & $\begin{array}{l}\text { Point out by his finger } \\
\text { of the things that he } \\
\text { needs when he has } \\
\text { chance of choices }\end{array}$ & 8 & 1 & \\
\hline 5 & $\begin{array}{c}\text { Body movement } \\
\text { toward the weak } \\
\text { sounds like the voice } \\
\text { of time index. }\end{array}$ & 8 & 1 & $\begin{array}{l}\text {-Turns his head toward } \\
\text { loud sounds. } \\
\text { - Responds to the } \\
\text { movement of the weak } \\
\text { voices.... etc. } \\
\text { - His body moves toward } \\
\text { Strong Voices }\end{array}$ \\
\hline 6 & $\begin{array}{l}\text { Recoils of someone } \\
\text { touching his arm or } \\
\text { back }\end{array}$ & 8 & $\begin{array}{c}1 \text { more } \\
\text { appropriate with } \\
\text { Autism } \\
\text { spectrum }\end{array}$ & \\
\hline 7 & $\begin{array}{l}\text { Write his name when } \\
\text { asked to. }\end{array}$ & 7 & 2 after training & \\
\hline 8 & $\begin{array}{l}\text { Can communicate } \\
\text { through images }\end{array}$ & 8 & $\begin{array}{l}1 \text { more } \\
\text { appropriate with } \\
\text { autism }\end{array}$ & \\
\hline 9 & $\begin{array}{l}\text { Smiling expression of } \\
\text { happiness }\end{array}$ & 8 & 1 & \\
\hline 10 & $\begin{array}{l}\text { Refers to the } \\
\text { movements of his } \\
\text { hands that he is } \\
\text { hungry }\end{array}$ & 8 & 1 & $\begin{array}{l}\text { Expresses his body for his } \\
\text { sense of hunger. }\end{array}$ \\
\hline 11 & $\begin{array}{l}\text { Asks what he wants by } \\
\text { sign or vague voices }\end{array}$ & 8 & 1 & \\
\hline 12 & $\begin{array}{l}\text { Express his anger } \\
\text { through facial } \\
\text { expressions }\end{array}$ & 8 & 1 & \\
\hline 13 & $\begin{array}{l}\text { Can recognize words, } \\
\text { which has previously } \\
\text { seen. }\end{array}$ & 7 & 2 & \\
\hline 14 & $\begin{array}{l}\text { Smiling in response to } \\
\text { the presence of a } \\
\text { person familiar to him }\end{array}$ & 8 & 1 & \\
\hline 15 & $\begin{array}{l}\text { Smiling in the case of } \\
\text { hearing the voice of } \\
\text { someone lovely to him. }\end{array}$ & 8 & 1 & \\
\hline
\end{tabular}




\begin{tabular}{|c|c|c|c|c|}
\hline $\begin{array}{l}\text { Sentences } \\
\text { No. }\end{array}$ & Sentences & $\begin{array}{l}\text { Appropriate } \\
\text { dimension } \\
\text { sentence for } \\
\text { arbitrators }\end{array}$ & $\begin{array}{c}\text { Inappropriate } \\
\text { dimension } \\
\text { sentence for } \\
\text { arbitrators } \\
\end{array}$ & $\begin{array}{l}\text { Linguistic formulation } \\
\text { integrity after } \\
\text { amendment }\end{array}$ \\
\hline 16 & $\begin{array}{l}\text { Move his head toward } \\
\text { the sound. }\end{array}$ & 8 & $\begin{array}{l}1 \text { exchanged } \\
\text { with sentence } \\
(5)\end{array}$ & \\
\hline 17 & $\begin{array}{l}\text { Follow instructions } \\
\text { that require behavior } \\
\text { such as (give me the } \\
\text { game-come on). }\end{array}$ & 8 & 1 & \\
\hline 18 & $\begin{array}{l}\text { Shaking his head, } \\
\text { expressing his } \\
\text { understanding of what } \\
\text { is happening. }\end{array}$ & 8 & $\begin{array}{l}1 \text { repeated with } \\
\text { No. (3) }\end{array}$ & \\
\hline 19 & $\begin{array}{l}\text { Raises his arms in } \\
\text { response to the } \\
\text { presence of the } \\
\text { caregiver }\end{array}$ & 8 & $\begin{array}{l}1 \text { appropriate } \\
\text { with No. (4) }\end{array}$ & \\
\hline 20 & $\begin{array}{l}\text { Follows the movement } \\
\text { of his head a particular } \\
\text { voice within } \\
\text { background influences } \\
\text { (such as teacher's } \\
\text { voice during the } \\
\text { interview his } \\
\text { colleagues with each } \\
\text { other). }\end{array}$ & 8 & 1 & \\
\hline 21 & $\begin{array}{l}\text { Point out by his hand } \\
\text { on the things when he } \\
\text { want }\end{array}$ & 8 & $\begin{array}{l}1 \text { repeated with } \\
\text { No. (4) }\end{array}$ & \\
\hline 22 & $\begin{array}{l}\text { Laughing in } \\
\text { appropriate situations }\end{array}$ & 7 & 2 & $\begin{array}{l}\text {-Emotions of anger appear } \\
\text { if the situation required. } \\
\text { - Gives the reaction be } \\
\text { appropriate in different } \\
\text { situation }\end{array}$ \\
\hline 23 & $\begin{array}{l}\text { Screaming when any } \\
\text { change occurs in the } \\
\text { normal daily routine } \\
\text { for him. }\end{array}$ & 8 & $\begin{array}{l}1 \text { appropriate } \\
\text { with Autism } \\
\text { spectrum }\end{array}$ & \\
\hline 24 & $\begin{array}{l}\text { Head movement is } \\
\text { used to denote the } \\
\text { answer is yes. }\end{array}$ & 8 & $\begin{array}{l}1 \text { repeated with } \\
\text { No. (3) }\end{array}$ & \\
\hline 25 & $\begin{array}{c}\text { The movement of his } \\
\text { shoulders used to } \\
\text { denote the answer is } \\
\text { no. }\end{array}$ & 8 & $\begin{array}{l}1 \text { repeated with } \\
\text { No. (3) }\end{array}$ & \\
\hline
\end{tabular}

Note: Tow items were excluded of the LVC, 12 items were added of the non- LVC. 


\section{Data Analysis:}

at this section, researcher used $\mathrm{T}$ test by using statistical analysis of the data to answer the questions of the study, interpretation and discussion of results, in light of the theoretical framework and previous studies, the following detailed view of it:

\section{Results related to the first question:}

Are there any differences in the dimensions of linguistic communication between the Mild Intellectual Disability and Children with High Functioning Autism? To answer the first question of the study, Independent-Sample $\mathrm{T}$ test was used to verify the significance of differences between the average degree of linguistic communication between the mild intellectual children and children with autism with high functioning. Table 5 shows us the differences.

Test " $\mathrm{T}$ " of the significance of differences between the average degrees of linguistic communication between the mild intellectual children and autistic children with high functionality

\begin{tabular}{|c|c|c|c|c|c|c|}
\hline \multirow{2}{*}{ Significance } & \multirow{2}{*}{ T value } & \multicolumn{2}{|c|}{$\begin{array}{l}\text { Autistic Children } \\
\qquad(\mathrm{N}=30)\end{array}$} & \multicolumn{2}{|c|}{$\begin{array}{l}\text { Mild Intellectual Disability } \\
\qquad(\mathrm{N}=30)\end{array}$} & \multirow{2}{*}{$\begin{array}{l}\text { Dimensions of } \\
\text { communication }\end{array}$} \\
\hline & & $\begin{array}{l}\text { IStandard } \\
\text { deviation }\end{array}$ & $\begin{array}{l}\text { Arithmeti } \\
\text { c average }\end{array}$ & $\begin{array}{r}\text { Standard } \\
\text { deviation }\end{array}$ & $\begin{array}{c}\text { Arithmetic } \\
\text { average }\end{array}$ & \\
\hline 0.975 & 0.031 & 23.13 & 51.57 & 17.61 & 51.40 & $\begin{array}{l}\text { Linguistic verbal } \\
\text { communication }\end{array}$ \\
\hline 0.000 & 9.687 & 13.86 & 63.13 & 22.74 & 110.23 & $\begin{array}{l}\text { Linguistic and non-verbal } \\
\text { communication }\end{array}$ \\
\hline
\end{tabular}

Evidenced by the results of the analysis of the table 5 that there are significant differences in the average score of linguistic non-verbal communication domination between the mild intellectual disabilities children and autistic children with high functioning. For children with mild 
intellectual disabilities perform degree; the value of the "T" was 9.687 which is statistically significant at 0,01 .

While the results indicated that there were no statistically significant differences between the average score of the linguistic verbal communication domination between the children with mild intellectual disabilities and autistic children with high functionality, as the value of "T" was 0.031 , a non-statistically significant.

\section{Results related to the second question:}

Are there any differences in linguistic communication dimensions of the Mild Intellectual Disability according to age group (7 to less than 9) and (9 to 11 years)? To answer the second question of this study was first to verify the natural assumption that the distribution of the degree of communication with mild intellectual children according to the stage of age due to the small sample size, and through the use of Shapiro-Wilk test, which indicated that its results through Table 6 that the degree of communicate with mild intellectual children of achieving age groups came to assume a normal distribution.

Table 6: Shapiro test results assuming normal distribution of the degree of communication with mild intellectual children depending on the age group.

\begin{tabular}{|c|c|c|c|c|}
\hline \multicolumn{2}{|c|}{ (9 to 11) Years } & \multicolumn{2}{|c|}{ (7 to less than 9 years) } & \multirow{2}{*}{$\begin{array}{l}\text { Dimensions of } \\
\text { communication }\end{array}$} \\
\hline $\begin{array}{l}\text { Significance } \\
\text { viewing }\end{array}$ & Statistic & $\begin{array}{l}\text { Significance } \\
\text { viewing }\end{array}$ & Statistic & \\
\hline 0.344 & 0.937 & 0.746 & 0.963 & $\begin{array}{l}\text { Linguistic verbal } \\
\text { communication }\end{array}$ \\
\hline 0.314 & 0.934 & 0.554 & 0.952 & $\begin{array}{l}\text { Linguistic and non-verbal } \\
\text { communication }\end{array}$ \\
\hline
\end{tabular}


Based on Table 6 results relating to assuming distribution of grades normal, Independent-Sample $\mathrm{T}$ test) was used parametric and to verify the significance of differences between the average degree of communication with mild intellectual disability according to the stage of age, and Table 7 shows that:

Table 7: "T" Test for independent groups to verify the significance of differences between the average degrees of communication with mild intellectual disability according to the stage of age.

\begin{tabular}{|ccccccc|}
\hline & \multicolumn{2}{c}{ (9 to 11) Years } & \multicolumn{2}{c|}{ (7 to less than 9 years) } & \multicolumn{2}{c|}{$\begin{array}{c}\text { Dimensions of } \\
\text { communication }\end{array}$} \\
\hline $\begin{array}{c}\text { Significan } \\
\text { ce viewing }\end{array}$ & Value of $\mathbf{T}$ & $\begin{array}{c}\text { Standard } \\
\text { deviation }\end{array}$ & $\begin{array}{c}\text { Arithmetic } \\
\text { average }\end{array}$ & $\begin{array}{c}\text { Standard } \\
\text { deviation }\end{array}$ & $\begin{array}{c}\text { Arithmetic } \\
\text { average }\end{array}$ & \\
\hline 0.671 & 0.429 & 19.39 & 50.00 & 16.83 & 52.80 & $\begin{array}{c}\text { Linguistic verbal } \\
\text { communication }\end{array}$ \\
0.981 & 0.024 & 22.02 & 110.13 & 24.22 & 110.33 & $\begin{array}{c}\text { Linguistic and non-verbal } \\
\text { communication }\end{array}$ \\
\hline
\end{tabular}

Evidenced by the results of the analysis of Table 7 that there were no statistically significant differences between the average scores of linguistic communication dimensions (verbal and non-verbal) between the mild intellectual disabilities according to the stage of age, as were the values of " $T$ " to the dimensions of communication it is not statistically significant.

\section{Results related to the third question:}

Are there any differences in the dimensions of the language to communicate with autistic children those with high functioning according to age group (7 to less than 9) and (9 to 11 years)? To answer the third question of the study, first I check from the natural assumption that the distribution of the degree of communication due to the small sample size (as is the case in the previous question) so I have autistic children with high functionality according to the stage of age, through the use of Shapiro-Wilk 
test, which is indicated by the results of table 8 that the degree of communication with autistic children according to age group achieving came to assume a normal distribution.

Table 8: Shapiro-Wilk test assuming normal distribution of the degree of communication with autistic children according to age group

\begin{tabular}{|c|c|c|c|c|}
\hline \multicolumn{2}{|c|}{ (9 to 11) Years } & \multicolumn{2}{|c|}{ (7 to less than 9 years) } & \multirow{2}{*}{$\begin{array}{l}\text { Dimensions of } \\
\text { communication }\end{array}$} \\
\hline $\begin{array}{l}\text { Significance } \\
\text { viewing }\end{array}$ & Statistic & $\begin{array}{l}\text { Significance } \\
\text { viewing }\end{array}$ & Statistic & \\
\hline 0.741 & 0.963 & 0.111 & 0.904 & $\begin{array}{l}\text { Linguistic verbal } \\
\text { communication }\end{array}$ \\
\hline 0.315 & 0.934 & 0.221 & 0.924 & $\begin{array}{l}\text { Linguistic and non-verbal } \\
\text { communication }\end{array}$ \\
\hline
\end{tabular}

Based on Table 8 results relating to assuming distribution of grades normal, Independent-Sample $\mathrm{T}$ test was used parametric and to verify the significance of differences between the average degree of communication with autistic children according to the stage of age, and Table 9 shows that. Table 9: " $\mathrm{T}$ " test for independent groups to verify the significance of differences between the average degrees of communication with autistic children

\begin{tabular}{|c|c|c|c|c|c|c|}
\hline & & \multicolumn{2}{|c|}{ (9 to 11) Years } & \multicolumn{2}{|c|}{ (7 to less than 9 years) } & $\begin{array}{l}\text { Dimensions of } \\
\text { communication }\end{array}$ \\
\hline $\begin{array}{l}\text { Significan } \\
\text { ce viewing }\end{array}$ & Value of $T$ & $\begin{array}{l}\text { Standard } \\
\text { deviation }\end{array}$ & $\begin{array}{l}\text { Arithmetic } \\
\text { average }\end{array}$ & $\begin{array}{l}\text { Standard } \\
\text { deviation }\end{array}$ & $\begin{array}{c}\text { Arithmetic } \\
\text { average }\end{array}$ & \\
\hline 0.078 & 1.830 & 13.50 & 59.00 & 28.42 & 44.13 & $\begin{array}{l}\text { Linguistic verbal } \\
\text { communication }\end{array}$ \\
\hline 0.778 & 0.285 & 11.49 & 62.40 & 16.26 & 63.87 & $\begin{array}{l}\text { Linguistic and non-verbal } \\
\text { communication }\end{array}$ \\
\hline
\end{tabular}

According to the stage of age

Evidenced by the results of the analysis of the table 9 that there were no statistically significant differences between the average degree of communication between autistic children according to the stage of age, it 
came as the values of " $\mathrm{T}$ " to the dimensions of communication is not statistically significant.

\section{Discussion of the results:}

- Discuss the results of the first question: The results indicated that there are significant differences in the degree of linguistic non-verbal communication between the mild intellectual disability and autistic children with high functioning, In favor to disabled children perform the mild intellectual disability, suggesting that children with mild intellectual disability are better able to use the means of communication in express non-verbal about their needs and desires, compared degree continues to autistic children with high functioning, and despite the fact that the most important characteristics and qualities of disabled children with mild intellectual in terms of the evolution of language and unsatisfactory, which confirmed previous studies that have delayed and slow language development in general, and that appears mild intellectual disability in the early years and then be clear and varying the bigger the child's progress with age and the time of these characteristics of slow linguistic improve the mentally handicapped children, according to many studies seem to be comprehensive for each language that can be identified tags results expressive and receptive, where they appear in the understanding of mentally handicapped children to the language of audio features and, in expressing her spoken sounds of the different meanings also it includes rules to build the language that acquired most of the mild intellectual disability, but at a slower rate compared with norm children and a higher rate than children with autism with high functioning .The consistent results of this study with the study of each 
of the Wabili (2003) that some of the results of the existence of a variety of verbal problems among students with mild intellectual disability, studying Abdetto, Firman, and Davis (1994), reported the existence of a negative correlation between the understanding of verbal and level of intellectual disabilities, the study Dosari (2010), which results from the existence of deficiencies in expressive and receptive language vocabulary in children with autism.

- Discuss the results of the second question: The results showed for the second question, there are no statistically significant differences in the degree of communication with children with mild intellectual disability according to stage age. Researcher is attributed that children with mild intellectual disability depending on the age groups are facing disruption in the communication process, illustrated through deficiencies in their ability to interact and communicate with others, and as a result they are unable to meet their desires and their expression and therefore they need to help others, and this is reflected deficits in all aspects of their lives. Researcher see that children with mild intellectual disability suffering from a general lack of language development and problems of private use language and speech disorders, speech and language content in the diminutive. children with mild intellectual disability a vary in linguistic characteristics depending on the severity of disability, those children are characterized by the growth of social and motor and verbal skills and approaching normal children to the point that he is not the discovery of this kind, but in the age of the school, where they need to take care of their years of study in the first, and thus they stumble and fail in recent academic years, i.e., in the age of (10-12) years. The linguistic 
characteristics and problems associated longer look accompanies mental disability, because they affect the communicative power of mentally handicapped children, and thus lead to weakness or language and verbal delays. And his words are often confused in terms of fluency or speech or audio, and notes on the disabled mentally difficult to acquire advanced language skills, and therefore suffers from the problems of different linguistic, such as delayed language development expressive language and communication. Also, the use of grammar wrong way and always uses a simple vocabulary does not commensurate with chronological age, and is linked to the spread and severity of the language and verbal problems when severely mentally disabled and mental disabilities and different degrees, and the greater the severity of mental disabilities increased the intensity of the verbal and language disorders are becoming more prevalent.

- Discuss the results of the third question: The results of the third study shows that there are no significant differences statistically in the degree of linguistic communication verbal and non-verbal communication between autistic children according to the stage of age, and attributes the researcher reminded to negative trends in Arab environments with respect to how to deal with this category by isolating them from the surrounding environment, this in turn adversely affect the linguistic communication verbal and non-verbal have across different developmental stages, and considers the researcher that autistic children with high functioning is able to develop relationships with others through different stages of growth have the result of not mixing with others, and lack of awareness of community members of the importance 
of programs early intervention for the development of language and communication skills in the early years of a child with a disability age, in addition to the requirements of this intervention efforts and expensive process may lead to the failure of many educational and social institutions thinking about creating this kind of care for children under study programs. So we find that besides guiding therapy of early intervention for the development of language skills and communicate uncharacteristically in educational organized a special program, and found it to be weak does not achieve the desired objectives to the fullest, and is supported by what I said Kanner study referred to in Zraiqat (2004) that the characteristic behaviors of children autism, which include the inability to develop relationships with others, and the delay in the acquisition of speech, repeated activities play module, in addition to the lack of exchange of information, feelings and ideas and beliefs with his peers, all of that would have a negative impact on the acquisition of skills to communicate with others, and are consistent as a result of this the question also with Dosari study (2010) revealed findings that autistic children range in different stages of life characteristics were similar in all the dimensions of receptive vocabulary, expressive, and the total score, as well as with the study of each of the Jrzyn, Grazin (2008) and study the Planck and Adrian, Blank \& Adrian (2005), as well as with the results of Nottrdam, Raidt, Hun study (2009), which reported that the verbal IQ rate among children with higher than autistic children with high functioning of Asperger syndrome because language skills have higher, and that autistic children with high functioning. They have problems with 
language and problems of mobility, as well as Kelly study (2006), which indicated the results that the grades of children in receptive and expressive language was within the normal range, and there are differences in receptive language for the benefit of ordinary children, while the results reported that there are no differences between normal children and children have a history of autistic and autistic children with functionality high in the language, and that there are no differences in the groups in linguistic structures, and the scores of children who have a history of autism and autistic children with job performance high was within the normal range, while ordinary children received the highest rate in this test.

\section{Internal Validity:}

1- Selection: one important consideration is selection weather is sample is similar to larger population. The schools that I selected in the sample are very similar to large population in Saudi Arabia. Selection is one of the problem. Also, through the comparing with the demographics of my sample who are students with mild intellectual disabilities and autistic students with high functioning to the demographics of my population, I confirm that they are similar at all Saudi Arabia's school.

2- Instruments decay: the amount of time that took to deliver the scale may impact the results. The longer it takes to deliver the scales, the more chance that there will be errors in the result of the scale especially that are some of the sentences at the scale needs training and continues observation, so the late of delivering the scale may impact the time, students mood, and the final result. 


\section{External Validity:}

Participant and Time: these factors are relevant to other due to the existence of some of the social determinants of privacy in the intellectual education programs for boys, researcher have suffered of being able to get delivery of the scale to the schools that have been selected for the application has been applied and the data collection a long period of study leave during which the process has continued, leading to the length of the application of the scale.

\section{Reflection:}

In light of the findings of Conclusion Recommendation study results, the researcher proposes a number of recommendations, which are the following:

The need for communication between competent centers to deal with children with mild intellectual disability and autistic children to learn about their problems and their needs and to provide training and guidance programs for parents in order to guide them to the best techniques and methods of education and training for disabled children and those with autism.

- Training and extension programs prepare a variety of stimuli that fit the capabilities of children with mild intellectual disability, as well as autistic children with high functionality.

- Encouraging parents to need to exercise natural outreach activities in their children's language learning and communication.

- Provide intellectual institutions and institutes of education training and extension programs which are based on scientific and 
educational foundations in the training and education of mentally handicapped children and those with autism, as well as training employees how to apply them and employ them in the manner that ensures benefit.

- Directing parents to the need to meet the child's basic need to communicate with others through a visually and emotionally by seeing what is going on around him, it should not be this child feel isolated or be left alone.

- Instruct parents and make them aware of the importance of early detection of mentally handicapped children or children with autism and the difficulties that may be encountered in the matter of this disclosure.

- Instruct parents and direct them to ways to deal effectively with disabled children or children with autism, and how to help their children through programs that contribute to the development of their skills in language and communication.

- Work on the establishment of a solid relationship between the guardian of a disabled child or a child with autism, and a specialist in order to ensure the provision of useful and appropriate educational opportunities for the upbringing and development of language skills and communicate with a disabled child or a child with autism.

- The need to provide curricula are working on the development of the skills of mentally disabled children and children with autism in language and communication is based on the principles of plain language development foundations. 


\section{Also, there are the following Recommendations to the current} researchers:

- The effectiveness of a guiding program for the development of linguistic communication skills verbal and non-verbal communication with mentally handicapped children and the simple degree of autistic children with high functionality.

- Effectiveness of the software program in language and cognitive skills for children with mild intellectual disability.

- Conducting similar studies for the current study in Arab environments include different age categories of what I discussed the current study.

- Conducting similar studies include different disability and comparing the present study classes. 


\section{References}

Gillberg, C., \& Coleman, M. (2000). The biology of the autistic syndromes ( $3^{\text {rd }}$ ed.) London: Mackeith Press.

Taylor, R., Smiley, L., \& Richards, S. (2015). Students with Intellectual Disabilities. In Exceptional students: Preparing teachers for the 21st century (Second ed., pp., 236,237). Boston: McGrawHill Higher Education.

Beblawi, Suleiman, and Ihab Abdel-Hamid. (2006). Evaluation and diagnosis in special education. Riyadh: Dar al-Zahra.

Body, Mona. (2005). Reading and writing difficulties and strategies to treat. Cairo: Zahra Middle Library.

Shash, Suhair al. (2007). Diagnosis, causes and treatment of communication disorders. Cairo: Zahra

AlSharq Printing, Publishing.

Rousan, Farouk. (2017). The psychology of exceptional children Introduction to Special Education. Amman: Dar alfeker

Alqraiti, Abdul Muttalib. (2005). Psychology with special needs and their upbringing. Dar Arab alfeker

Jetaili, Abdullah. (2009). Vocabulary characteristics of the mild children with intellectual disabilities in pre-school phase of the Kingdom of Bahrain. (Unpublished MA Thesis). Arabian Gulf University, Bahrain.

Heran, Abeer. (2009). Level of understanding of linguistic structures in children with mild intellectual disabilities in pre-school phase of the Kingdom of Bahrain. (Unpublished MA Thesis). Arabian Gulf University, Bahrain. 
Grazian, R. (2008). Non-verbal communication skills in young children with autism. Journal of autism \& developmental disorder, 39(, 9), p.p.130: 145

Smith,v. Miranda, p. \& Zoaidman-zait,A. (2007). Predictors of Expressive vocabulary growth in children with Autism, Journal of speech language، (3) p.p ،623-657.

Dossary, khloud. (2010). Social interaction and its relationship with some language communication skills in children with autism in Kuwait. (A magister message that is not published). Gulf Arab University, Kingdom of Bahrain.

Zureiqat, Ibrahim. (2004). Autism characteristics and treatment. Amman: Dar Al-Fikr.

Wabli, Abdullah. (2003). The nature of the verbal problems in the students and the range of mental retardation and its relation to some personal variables. Journal of Psychological Counseling, Ain Shams University. Issue (16), 60

Blank,1,\& Adrian,j.(2005). Dysregulation of pretend play \& communication development in children with autism. Journal of research \& practice ‘(9)p.p، 229-245.

Kelley, E. (2006). language profiles of high-functioning children withautism \& children ahistory of autism. (Ph.D. Dadissertation university of Conneeticut. U.S.A. 